\title{
ANALISIS KEMAMPUAN BERPIKIR TINGKAT TINGGI MAHASISWA PADA MATA KULIAH METODE STATISTIKA DI ERA PANDEMI COVID-19
}

\author{
I Putu Ade Andre Payadnya, I Ketut Suwija \\ Universitas Mahasaraswati Denpasar, Jl. Kamboja No.11A, Kota Denpasar, Bali 80233 \\ E-mail: adeandre@unmas.ac.id
}

\begin{abstract}
Abstrak
Perubahan besar dalam bidang pendidikan yang disebabkan oleh Pandemi Covid-19 menyebabkan penurunan kemampuan berpikir siswa. Oleh karena itu, sangat penting untuk menganalisis bagaimana tingkat kemampuan berpikir siswa di era ini. Tujuan dari penelitian ini adalah untuk menganalisis kemampuan berpikir tingkat tinggi matematika siswa pada era Pandemi Cocid-19 dengan menggunakan tiga tahapan metaphorical thinking. Penelitian ini dilaksanakan pada semester Genap. Subjek dalam penelitian ini adalah 11 siswa kelas IIB Program Studi Pendidikan Matematika Universitas Mahasaraswati Denpasar, Indonesia. Penelitian ini menggunakan teknik analisis deskriptif. Pengumpulan data dilakukan melalui tes, wawancara, observasi, dan dokumentasi. Hasil penelitian menunjukkan bahwa kemampuan berpikir tingkat tinggi matematika siswa sangat rendah dimana hanya $20 \%$ siswa menjawab benar pada tahap grounding metaphors, $25 \%$ pada tahap linking metaphors, dan hanya $25 \%$ pada tahap redefinitional metaphors. Secara umum, fenomena ini terjadi dikarenakan berkurangnya kesempatan siswa untuk berinteraksi dan berdiskusi saat pembelajaran daring di era Pandemi yang juga menyebabkan kurangnya kesempatan siswa untuk saling bertukar pemahaman dan pengetahuan. Siswa juga tidak dapat memahami masalah secara mendalam dan menghubungkan konsep dengan kehidupan sehari-hari.
\end{abstract}

Kata Kunci: Pandemi Covid-19, Analisis Deskriptif, Keterampilan Berpikir Tingkat Tinggi, Metode Statistik

\begin{abstract}
Major changes in education caused by the Covid-19 Pandemic led to a decrease in students' thinking skills. Therefore, it is very important to analyze how the level of thinking ability of students in this era. The purpose of this study was to analyze students' higher order mathematical thinking skills in the era of Covid-19 Pandemic by using three stages of metaphorical thinking. This research was conducted in the even semester. The subjects in this study were 11 students of class IIB Mathematics Education Study Program, Universitas Mahasaraswati Denpasar. This research uses descriptive analysis techniques. Data collection was carried out through tests, interviews, observation, and documentation. The results showed that the students' high-order mathematical thinking skills were very low where only $20 \%$ of students answered correctly at the grounding metaphors stage, $25 \%$ at the linking metaphors stage, and only $25 \%$ at the redefinitional metaphors stage. In general, this phenomenon occurs due to the reduced opportunities for students to interact and discuss during online learning in the Pandemic era which also results in a lack of opportunities for students to exchange understanding and knowledge. Students also cannot understand problems in depth and relate concepts to everyday life.
\end{abstract}

Keywords: Covid-19 Pandemic, Descriptive Analysis, High-Order Thinking Skills, Statistic Method 


\section{PENDAHULUAN}

Pendidikan merupakan aspek yang sangat berperan dalam perkembangan dari sebuah bangsa. Karena hal tersebut, peningkatan sektor pendidikan sangat penting untuk meningkatkan kualitas sumber daya manusia yang nantinya akan berperan dalam kemajuan dari bangsanya. Sektor pendidikan selama ini juga mengalami beebagai perubahan yang sangat signifikan sehingga berpotensi menimbulkan era disrupsi yang sangat berpengaruh bagi paradigma pendidikan kedepannya.

Krisis Pandemi COVID-19 telah mempengaruhi sistem pendidikan di seluruh dunia dan serta menimbulkan peradaban baru dalam dunia pendidikan yang memicu reformulasi aktivitas pembelajaran (Tamur et. al, 2021). Berbagai tatanan di bidang pendidikan terpaksa berubah dan menyebabkan berbagai permasalahan. Sebagai contoh, gelombang pembelajaran online yang tiba-tiba akibat Pandemi Covid-19 telah mengubah wajah dunia pendidikan di Indonesia dan menyebabkan ketidaksiapan baik dari guru maupun siswa. Farida et al (2020) menyatakan bahwa pembelajaran online menyebabkan penuruhan kemampuan pemahaman siswa karena kesulitan untuk beradaptasi dalam mengakses konten pembelajaran dengan baik.

Lebih lanjut Kusnayat et al (2020) menambahkan bahwa perkuliahan online yang dilakukan oleh dosen disertai dengan penugasan yang banyak sekali dalam wabah Pandemi Covid-19 sehingga menyulitkan mahasiswa untuk bergerak dalam menyelesaikan tugasnya melalui interaksi antar mahasiswa seperti biasanya. Selain itu, menurut Lisnani dan Tanujaya (2021), salah satu kesulitan utama yang dihadapi mahasiswa dalam pembelajaran online adalah kualitas jaringan internet yang kerap tidak stabil. Berbagai permasalahan tersebut menyebabkan menurunnya kualitas hasil belajar mahasiswa.

Dilain pihak, keberhasilan pembelajaran matematika modern sangat bergantung pada kemampuan berpikir tingkat tinggi siswa. Kemampuan berpikir tingkat tinggi atau yang biasa disebut Higher-Order Thining Skills (HOTS) merupakan proses berpikir siswa pada tingkat kognitif yang lebih tinggi yang dikembangkan dari berbagai konsep dan metode kognitif serta taksonomi pembelajaran seperti metode pemecahan masalah, bloom taksonomi, dan taksonomi pembelajaran, pengajaran, dan penilaian. (Saputra, 2016). HOTS meliputi kemampuan pemecahan masalah, keterampilan berpikir kreatif, berpikir kritis, kemampuan argumentatif, dan kemampuan pengambilan keputusan (Dinni, 2018). 
Menurut Tanujaya dan Mumu (2020), HOTS akan muncul ketika seseorang mengaitkan informasi baru dengan berbagai informasi yang sudah tersimpan di dalam ingatannya dan mengaitkannya dan/atau menata ulang serta mengembangkan informasi tersebut untuk mencapai suatu tujuan atau menemukan suatu penyelesaian dari suatu keadaan yang sulit dipecahkan. Dari beberapa uraian tersebut, dapat disimpulkan bahwa memiliki HOTS yang baik dapat menuntun siswa untuk dapat memahami konsep serta menyelesaikan berbagai permasalahan matematika sehingga siswa akan mencapai keberhasilan dalam pembelajaran matematika.

Tujuan utama dari pembelajaran berbasis HOTS adalah bagaimana meningkatkan kemampuan berpikir peserta didik pada level yang lebih tinggi, terutama yang berkaitan dengan kemampuan untuk berpikir secara kritis dalam menerima berbagai jenis informasi, berpikir kreatif dalam memecahkan suatu masalah menggunakan pengetahuan yang dimiliki serta membuat keputusan dalam situasi-situasi yang kompleks (Saputra, 2016). Oleh karena hal tersebut, HOTS sangat penting bagi siswa untuk memperoleh keberhasilan dalam pembelajaran matematika. HOTS juga sangat penting bagi kemajuan sumber daya manusia serta peningkatan kualitas pendidikan, daya saing, daya pikir, serta kemajuan teknologi yang dimiliki bangsa.

Pentingnya kemampuan berpikir tingkat tinggi ternyata tidak serta merta membuat Indonesia berada pada zona yang “aman”. Dalam hal HOTS, Indonesia masih tergolong tertinggal dari negara-negara lainnya. Terbukti rangking siswa Indonesia pada PISA dan TIMSS (2015), Indonesia menduduki peringkat ke-64 dari 72 negara yang berpartisipasi pada PISA, dan menduduki peringkat ke-45 dari 48 negara yang berpartisipasi pada TIMSS (Nugroho, 2018). Dari hasil survei ini terlihat bahwa HOTS atau kemampuan berpikir tingkat tinggi siswa di Indonesia masih kurang.

Pentingnya HOTS bagi keberhasilan pendidikan matematika serta banyaknya perubahan yang terjadi di era menyebabkan seorang tenaga pendidik harus mampu menganalisis bagaimana HOTS yang dimili siswa di era ini. Hasil analisis yang dipeoleh akan menjadi dasar bagi tenaga pendidik untuk menentukan strategi ataupun metode yang sesuai untuk keberhasilan pembelajaran matematika. Salah satu cara untuk menganalisis HOTS siswa adalah menggunakan instrumen yang berbasis metaphorical thinking.

Metaphorical thinking sangat erat kaitannya dengan kemampuan berpikir tingkat tinggi (Nurhikmayati, 2017). Hal ini karena metaphorical thinking berfokus pada 
pengembangan kemampuan berpikir lanjutan untuk menghubungkan konsep matematika dengan fenomena nyata yang ada di sekitar siswa (Carreira, 2001: 67). Metaphorical thinking menggunakan metafora sebagai konsep dasar dalam berpikir. Akibatnya, beberapa konsep matematika yang dipelajari berdasarkan pengalaman siswa dapat dengan mudah membangun model matematika dengan interpretasi yang akurat (Hendriana, 2012).

Metaphorical thinking adalah kemampuan untuk memodelkan situasi matematis yang ditafsirkan dari perspektif semantik menggunakan metafora. Menurut Holyoak \& Thagard (Hendriana, 2012), metafora dimulai dengan konsep yang diketahui siswa hingga konsep lain yang belum diketahui atau sedang dipelajari oleh siswa. Sedangkan menurut Hendriana, et al (2017), konsep berpikir yang menekankan pada kemampuan menghubungkan ide matematika dengan fenomena yang ada adalah berpikir metaforis. Dari pemaparan tersebut, metaphorical thinking sangat tepat digunakan untuk mengukur bagaimana kemampuan berpikir tingkat tinggi yang dimiliki siswa.

Untuk dapat menganalisis HOTS siswa menggunakan instrumen berbasis metaphorical thinking, diperlukan tahapan-tahapan yang menjadi dasar dari konsep metaphorical thinking skills. Tiga tahapan tersebut diantaranya: (1) grounding metaphor: merupakan dasar pemahaman ide matematika yang berhubungan dengan pengalaman sehari-hari (2) linking metaphor: membangun keterkaitan antara dua hal yaitu memilih, menegaskan, memberi kebebasan, dan mengorganisir ciri-ciri dari topik utama didukung oleh topik tambahan berupa pernyataan metafora (3) redefinitional metaphor: mendefinisikan kembali metafora tersebut dan memilih yang paling sesuai dengan topiknya (Mardiyanti et al, 2018). Tahapan-tahapan ini berikutnya akan menjadi landasan dalam pembentukan instrumen untuk menganalisis HOTS yang dimiliki siswa.

Perubahan-perubahan dalam pembelajaran ini tentunya akan mempengaruhi kemampuan berpikir tingkat tinggi yang dimiliki mahasiswa. Guna memahami berbagai perubahan yang terjadi dalam pendidikan matematika, serta mengetahui kemampuan berpikir tingkat tinggi mahasiswa, maka dilaksanakan penelitian. Penelitian ini bertujuan untuk melakukan analisis kemampuan berpikir tingkat tinggi matematika tinggi mahasiswa di era Pandemi Covid-19. Hasil penelitian diharapkan dapat diperoleh informasi faktor-faktor yang mempengaruhi kemampuan berpikir tingkat tinggi mahasiswa pada mata kuliah Metode Statistika di era Pandemi Covid-19. 


\section{METODE PENELITIAN}

Penelitian dilaksanakan dengan menggunakan metode penelitian kualitatif yang bertujuan untuk menunjukkan secara lebih cermat kemampuan berpikir tingkat tinggi mahasiswa pada mata kuliah Metode Statistika pada era disrupsi pendidikan akibat Pandemi Covid-19. (Moleong, 2014) juga mendefinisikan kualitatif sebagai penelitian yang bermaksud untuk memahami tentang fenomena apa yang dialami oleh subjek penelitian, seperti perilaku, persepsi, motivasi, dan tindakan secara holistik dengan cara deskripsi dalam bentuk kata-kata, bahasa, pada suatu konteks khusus yang alamiah dengan memanfaatkan berbagai metode alamiah.

Penelitian ini dilaksanakan dengan menggunakan metode penelitian deskriptif kualitatif. Menurut Sugiyono (2005), metode deskriptif adalah suatu metode yang digunakan untuk menggambarkan atau menganalisis suatu hasil penelitian tetapi tidak digunakan untuk membuat kesimpulan yang lebih luas. Penelitian ini dideskripsikan untuk mengumpulkan informasi mengenai kemampuan berpikir tingkat tinggi mahasiswa melalui tiga tahapan metaphorical thinking, yaitu: grounding metaphor, linking metaphor, dan redeinitional methaphor.

Populasi penelitian adalah mahasiswa Pendidikan matematika, dengan populasi target adalah mahasiswa Pendidikan Matematika Universitas Mahasaraswati Denpasar. Sampel dalam penelitian ini adalah 11 orang mahasiswa kelas IIB Program Studi Pendidikan Matematika. Penentuan sampel dilakukan secara purposif, dengan memilih mahasiswa yang memiliki tiga tahapan berpikir tingkat tinggi metaphorical thinking.

Data primer diperoleh dari hasil jawaban siswa dalam mengerjakan soal uraian dan wawancara yang dilakukan terhadap mahasiswa. Sedangkan, data sekunder dari literatur, website dan dokumen berupa nilai matematika siswa pada semester sebelumnya.

Pengumpulan data primer dilakukan dengan menggunakan instrument tes. Menurut Arikunto (2012:46) tes adalah serentetan pernyataan atau latihan serta alat lain yang digunakan untuk mengukur keterampilan, pengetahuan intelegensi, kemampuan atau bakat yang dimiliki oleh individu atau kelompok. Pemberian tes ini bertujuan untuk memperoleh data dan bahan pengamatan mengenai kesalahan siswa dalam menyelesaikan soal - soal metode statistika, khususnya normalitas data dan homogenitas varians.

Guna meningkatkan validitas data, maka dilakukan wawancara. Wawancara 
menurut Sugiyono (2012) adalah pengumpulan data apabila peneliti ingin melakukan studi pendahuluan untuk menemukan permasalahan yang harus diteliti, tetapi apabila peneliti ingin mengetahui hal-hal dari responden yang lebih mendalam. Wawancara yang digunakan dalam penelitian ini adalah wawancara tidak terstruktur dengan menyusun pedoman wawancara yang hanya memuat garis - garis besar yang akan ditanyakan. Pada pedoman ini lebih memerlukan kreativitas dari pewawancara, bahkan hasil wawancara dengan jenis pedoman ini lebih banyak tergantung dari pewawancara. Wawancara ini bertujuan untuk mengetahui faktor - faktor yang menyebabkan terjadinya hambatan atau kesulitan yang dialami mahasiswa.

Lebih lanjut, menurut Sugiyono (2012), uji kredibilitas data atau kepercayaan terhadap data hasil penelitian kualitatif antara lain dilakukan dengan perpanjangan pengamatan, peningkatan ketekunan dalam penelitian, triagulasi, diskusi dengan teman sejawat, analisis kasus negatif, dan member check. Teknik analisis data deskriptif kualitatif yang digunakan dalam penelitian ini dengan tahapan reduksi data, verifikasi, pengecekan data, dan penarikan kesimpulan.

\section{HASIL DAN PEMBAHASAN}

\section{Hasil Analisis Data}

Hasil yang diperoleh dalam penelitian ini menunjukkan rendahnya kemampuan berpikir tingkat tinggi yang dimiliki mahasiswa. Hal tersebut bila ditinjau dari tiga tahapan metaphorical thinking dalam mata kuliah Metode Statistika, sebagaimana disajikan pada Tabel 1.

Tabel 1. Rekapitulasi Jawaban Mahasiswa

\begin{tabular}{lccc}
\hline \multicolumn{1}{c}{ Tahap } & $\begin{array}{c}\text { Banyak Mahasiswa } \\
\text { Menjawab Benar }\end{array}$ & $\begin{array}{c}\text { Banyak Mahasiswa } \\
\text { Menjawab Salah }\end{array}$ & $\begin{array}{c}\text { Persentase } \\
\text { Jawaban Benar }\end{array}$ \\
\hline $\begin{array}{l}\text { Grounding } \\
\text { metaphors } \\
\text { Linking } \\
\text { metaphors } \\
\text { Redefinitional } \\
\text { metaphors }\end{array}$ & 4 & 16 & $20 \%$ \\
\hline
\end{tabular}




\section{Grounding Metaphor}

Pada tahap ini, mahasiswa disuguhkan dengan metafora yang telah disusun sebelumnya. Mereka diminta untuk memahami metafora tersebut serta menjelaskan konsep statistik yang ada di bawah metafora tersebut. Salah satu contoh masalahnya adalah: "Ada hutan yang hanya tumbuh satu jenis tumbuhan atau bisa dikatakan hanya satu variasi. Setiap tumbuhan memiliki ciri yang sama karena berasal dari spesies yang sama, namun setiap pohon merupakan individu yang berbeda. Contoh hutan tersebut adalah hutan pinus. Konsep statistika apa yang cocok dengan metafora ini? Jelaskan. "

Metafora yang disajikan mengacu pada konsep homogenitas varians. Namun, sebagian besar mahasiswa tidak dapat memahami konsep yang dirujuk dan memberikan jawaban yang salah. Banyak mahasiswa yang memberikan jawaban bahwa konsep yang dimaksud adalah konsep rata-rata karena hutan yang ditumbuhi pohon yang sama dapat dikatakan bahwa rata-rata pohon yang ada di hutan itu sama. Contohnya seperti hutan pinus yang rata-rata ditumbuhi pohon pinus. Berikut salah satu jawaban mahasiswa dalam tahap Grounding Metaphor, sebagaimana disajikan pada Gambar 1.

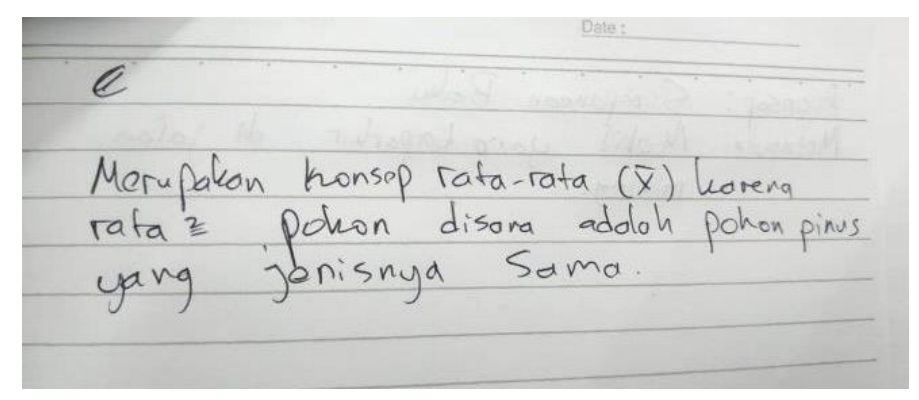

Gambar 1. Contoh Jawaban Mahasiswa dalam Tahap Grounding Metaphor

Hal ini menunjukkan bahwa mahasiswa kurang mendalam dalam memahami konsep, sehingga ketika dihubungkan dengan metafora, mahasiswa hanya menggunakan padanan kata-kata yang dirasa tepat atau melekat dalam pemikirannya. Hal tersebut menunjukkan rendahnya kemampuan berpikir tingkat tinggi yang dimiliki oleh mahasiswa. Selain itu, beberapa mahasiswa telah berhasil menjawab homogenitas varians tanpa memberikan penjelasan rinci tentang hubungan konsep dengan metafora. 


\section{Linking Metaphor}

Pada tahap ini, mahasiswa diberikan dua konsep dan metafora yang harus mereka pasangkan satu sama lain. Namun, banyak mahasiswa yang salah memasangkan konsep dengan metafora, dan beberapa bahkan memasangkannya secara terbalik. Contoh Jawaban Mahasiswa dalam Tahap Linking Metaphor, disajikan pada Gambar 2.

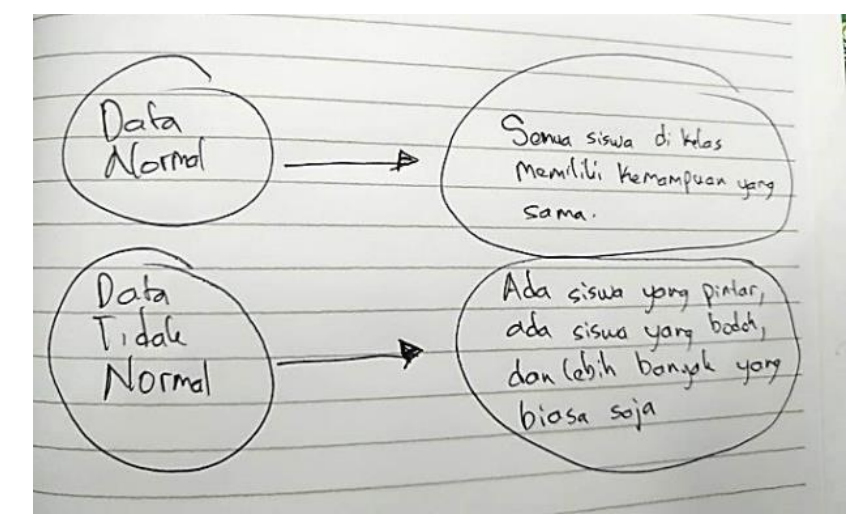

Gambar 2. Contoh Jawaban Mahasiswa dalam Tahap Linking Metaphor

Jawaban mahasiswa pada Gambar 2, terlihat jelas bahwa terdapat kurangnya kemampuan berpikir tingkat tinggi mahasiswa dalam memahami konsep dan mengaitkannya dengan fenomena dunia nyata yang disajikan dalam metafora. Konsep "data terdistribusi normal" dipasangkan dengan metafora "semua mahasiswa di kelas memiliki kemampuan yang sama untuk berada di tingkat menengah". Sedangkan konsep "data tidak berdistribusi normal" berpasangan dengan metafora "ada mahasiswa berkemampuan tinggi, ada mahasiswa berkemampuan rendah, dan banyak mahasiswa berkemampuan rendah di kelas". Hal ini salah karena definisi dari data berdistribusi normal itu sendiri adalah dalam datanya terdapat level tinggi, rendah, dan sebagian besar berada pada data level menengah seperti yang ditunjukkan juga pada kurva normal, namun siswa menganggap normal artinya tidak tinggi maupun rendah.

\section{Redefinitional Metaphors}

Pada tahap ini mahasiswa diberi konsep dan diminta menulis metafora yang mengikuti konsep tersebut. Namun sebagian besar mahasiswa hanya menulis kasus atau cerita masalah dari konsep yang diberikan. Hal ini tentu saja kurang tepat karena walaupun dalam beberapa kasus terkesan sama, pemikiran metaforis adalah hal yang 
berbeda dari cerita. Dalam berpikir metaforis, mahasiswa harus mampu membuat metafora yang memiliki ciri dan konsep yang sama dengan materi walaupun dalam domain yang berbeda (Kilic, 2010). Berpikir metaforis sendiri bukanlah sebuah konsep, melainkan cara memahami konsep melalui perumpamaan yang lebih sederhana, familiar, dan mudah dipahami mahasiswa. Contoh Jawaban Mahasiswa dalam Tahap Redefinitional Metaphor disajikan pada Gambar 3.

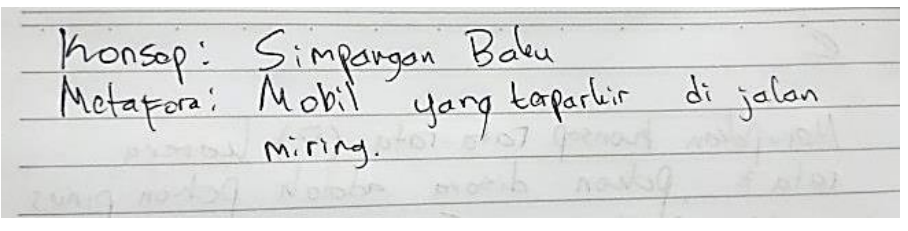

Gambar 3. Contoh Jawaban Mahasiswa dalam Tahap Redefinitional Metaphor

Selain dari banyaknya kekurangan, terdapat juga jawaban mahasiswa yang hampir benar namun masih terkendala oleh kurangnya penjelasan rinci yang diberikan tentang keterkaitan konsep dengan metafora. Untuk memperdalam analisis dan memperoleh penyebab pasti dari kurangnya kemampuan berpikir tingkat tinggi mahasiswa, dilakukan wawancara dengan perwakilan mahasiswa untuk melakukan konfirmasi lebih lanjut.

Dari hasil wawancara yang dilakukan dengan 5 orang perwakilan mahasiswa, sebagian besar mengaku kesulitan memahami tes keterampilan berpikir methaporical thinking yang disajikan secara online. Mereka menyatakan bahwa tidak adanya pembentukan kelompok dan diskusi membuat mereka sulit untuk bertukar pikiran dengan rekan kerja dalam mengerjakan masalah. Hal ini bertentangan dengan konsep pembelajaran konstruktivisme yang menekankan pada proses siswa bekerja sama dalam mengkonstruksi pengetahuannya. Mahasiswa lainnya mengklaim mengalami penurunan motivasi belajar selama masa pembelajaran online. Hal ini disebabkan kurangnya suasana belajar yang dirasakan siswa saat belajar dari rumah. Hal tersebut mengakibatkan kurangnya antusias mahasiswa dalam mengerjakan tes methaporical thinking yang disajikan sehingga jawaban mahasiswa kurang optimal. Hasil ini didukung oleh penelitian yang dilakukan oleh Tamur et al (2021) yang mengungkapkan bahwa Pembelajaran Berbasis Virtual (PBV) kurang efektif dan kurang memberikan dampak terhadap motivasi diri dan High Order Thinking Sklills (HOTS) mahasiswa.

Selain dampak negatif, mahasiswa juga menyampaikan dampak positif yang dirasakan selama kuliah statistika online. Efek positifnya adalah siswa lebih leluasa dalam 
mengakses internet sehingga jika dilihat dari durasi tes rata-rata siswa menjawab soal lebih cepat daripada pembelajaran tatap muka. Hal ini dikarenakan siswa dapat langsung mencari petunjuk untuk menjawab pertanyaan dengan mengakses internet terutama dengan materi statistika yang sumbernya banyak tersedia di internet.

Dari pembahasan-pembahasan yang telah disajikan, terlihat kurangnya kemampuan berpikir tingkat tinggi mahasiswa akibat pembelajaran daring di era disrupsi pendidikan. Mahasiswa terlihat kurang mampu memahami konsep maupun permasalahan yang disajikan dengan benar. Sesuai dengan pendapat dari menurut Newman dan Wehlage (Widodo, 2013), dengan kemampuan berpikir tingkat tinggi peserta didik akan dapat membedakan ide atau gagasan secara jelas, berargumen dengan baik, mampu memecahkan masalah, mampu mengkonstruksi penjelasan, mampu berhipotesis dan memahami hal-hal kompleks menjadi lebih jelas. Jadi, kurangnya kemampuan siswa dalam mehamai konsep maupun gagasan dan maksud dari permasalahan yang disajikan merupakan indikator dari kurangnya kemampuan berpikir tingkat tinggi siswa.

Selain kurangnya pemahaman, peneliti juga mengungkapkan bahwa terjadinya penurunan motivasi serta keaktifan siswa dalam pembelajaran. Hal ini sejalan dengan Cahyani, et al (2020) yang menemukan bahwa motivasi belajar mahasiswa menurun selama pembelajaran daring serta hanya sedikit siswa yang berpartisipasi dan aktif dalam pembelajaran. Penurunan motivasi ini juga akan mengakibatkan penurunan pada kemampuan berpikir tingkat tinggi mahasiswa yang juga akan mengurangi kualitas pembelajaran. Hal ini dikarenakan motivasi serta keaktifan merupakan salah satu faktor penentu keberhasilan pembelajaran (Emda, 2018).

Selain hal negatif, ditemukan juga dampak positif dari pembelajaran daring di era disrupsi pendidikan. Hal ini terlihat dari hasil wawancara yang memperlihatkan bahwa siswa cenderung merasa lebih mudah dalam memperoleh informasi dalam pembelajaran. Sesuai dengan pendapat Herliandry, et al (2020), pembelajaran daring membiasakan peserta didik untuk mengumpulkan dan mengelola informasi terkait tugas yang diberikan tanpa batasan ruang dan waktu. Hal ini merupakan perkembangan yang baik dikarenakan kemudahan dalam akses informasi akan membiasakan siswa untuk mencari dan mengumpulkan pengetahuannya sendiri sehingga juga dapat melatih kemampuan berpikir tingkat tingginya dengan lebih leluasa. 


\section{KESIMPULAN}

Mahasiswa kurang mampu memahami konsep statistika yang disajikan secara mendalam sehingga kurang mampu menerjemahkan makna konsep. Mereka kurang mampu mengaitkan konsep metode statistik dengan konsep kehidupan sehari-hari, belum mampu membedakan pertanyaan cerita dari pertanyaan berpikir metaforis. Selain itu, mahasiswa juga kesulitan berdiskusi saat belajar online, dan mengalami penurunan motivasi ketika menyelesaikan masalah statistik yang berorientasi pada kemampuan berpikir tingkat tinggi karena pembelajaran online. Selain itu, terdapat pula dampak positif yang dirasakan mahasiswa dimana mahasiswa merasa lebih bebas dengan memanfaatkan internet dan teknologi lainnya selama pembelajaran online.

\section{DAFTAR PUSTAKA}

Arikunto, Suharsimi. (2012). Prosedur Penelitian. Jakarta: Rineka Cipta.

Cahyani, A., Listiana, I. D., \& Larasati, S. P. D. (2020). Motivasi Belajar Siswa SMA pada Pembelajaran Daring di Masa Pandemi Covid-19. Jurnal Pendidikan Islam, 3(1), 123-140.

Carreira, S. (2001). Where There's a Model, There's a Metaphor: Metaphorical Thinking in Student's Understanding of a Mathematical Model. Journal of International Mathematical Thinking and Learning, 3(4), 261-287.

Chandio, T. C., Padhiani, S. M., \& Iqbal, R. (2016). Bloom's Taxonomy: Improving Assessment and Teaching-Learning Process. Journal of Education and Education Development, 3(2), 203-221.

Dantes, Nyoman. 2012. Metode Penelitian. Yogyakarta: ANDI.

Dinni, H., 2018. "HOTS (High Order Thinking Skills) dan Kaitannya dengan Kemampuan Literasi Matematika.” PRISMA, Prosiding Seminar Nasional Matematika, 1, 170-176.

Emda, Amna. (2018). Kedudukan motivasi belajar siswa dalam pembelajaran. Lantanida Journal, 5(2), 172-182.

Farida, I., Sunarya, R.R., Aisyah, R., \& Helsy, I. (2020). Pembelajaran Kimia Sistem Daring di Masa Pandemi Covid-19 Bagi Generasi Z (Karya Tulis Ilmiah (KTI) Masa Work From Home (WFH) Covid-19). UIN Sunan Gunung Djati Bandung 2020. 
Gunawan, Suranti, N. M. Y., \& Fathoroni. (2020). Variations of Models and Learning Platforms for Prospective Teachers During the COVID-19 Pandemic Period. Indonesian Journal of Teacher Education, 1(2), 61-70.

Hendriana, H. (2012). Pembelajaran Matematika Humanis dengan Metaphorical Thinking untuk Meningkatkan Kepercayaan Diri Siswa. Infinity, 1(1), 90-103.

Hendriana, H., Rohaeti, E. E., \& Wahyu, H. (2017). Metaphorical Thinking Learning and Junior High School Teachers' Mathematical Questioning Ability. Journal on Mathematics Education, 8(1), 55-64).

Herliandry, L. D., dkk. (2020). Pembelajaran Pada Masa Pandemi Covid-19. Jurnal Teknologi Pendidikan, 22(1), 65-70.

Lisnani, \& Tanujaya, B. Respon Mahasiswa terhadap Perkuliahan Online pada Pembelajaran Matematika di Masa Pandemi Covid-19. Journal of Honai Math, $4(1), 67-84$.

Kusnayat, A., Muiz, M. H., Sumarni, N., Mansyur, A. S., \& Zaqiah, Q. Y. (2020). Pengaruh Teknologi Pembelajaran Kuliah Online di Era COVID-19 dan Dampaknya Terhadap Mental Mahasiswa. EduTeach : Jurnal Edukasi dan Teknologi Pembelajaran, 1(2), 153-165.

Mardiyanti, D.O. dkk. (2018). Analisis Kemampuan Berpikir Kritis Matematik Siswa Smp Pada Materi Segitiga Dengan Pendekatan Metaphorical Thinking. Jurnal Pembelajaran Matematika Inovatif, 1(3), 427-434.

Moleong, L. (2014). Metodologi Penelitian Kualitatif. Edisi Revisi. Bandung: PT Remaja Rosdakarya.

NCTM. (2000). Principles and Standards for School Mathematics. USA: NCTM.

Nugroho, R. (2018). HOT (Kemampuan Berpikir Tingkat Tinggi: Konsep, Pembelajaran, Penilaian dan Soal-Soal). PT Gramedia Widiasarana Indonesia.

Purwanto, A., Pramono, R., Asbari, M., Santoso, P. B., Wijayanti, L. M., Hyun, C. C., \& Putri, R. S. (2020). Studi Eksploratif Dampak Pandemi COVID-19 Terhadap Proses Pembelajaran Online di Sekolah Dasar. Journal of Education, Psychology, and Counseling, 2, 1-12.

Saputra, H. (2016). Pengembangan Mutu Pendidikan Menuju Era Global: Penguatan Mutu Pembelajaran dengan Penerapan HOTS (High Order Thinking Skills). Bandung: SMILE's Publishing. 
Setiawan, H., Dafik., \& Diah, N. 2014. Soal Matematika dalam PISA Kaitannya dengan Literasi Matematika dan Keterampilan Berpikir Tingkat Tinggi. In Prosiding Seminar Nasional Matematika. Jember.

Sugiyono. (2005). Memahami Penelitian Kualitatif. Bandung: CV. Alfabeta.

Sugiyono. (2012). Motode Penelitian Kombinasi (Mixed Methods). Bandung: Alfabeta.

Tamur, M., Jehadus, E., Negara, H. R. P., Siagian, M. D., Marzuki, \& Sulastri, R. (2021). Pembelajaran Selama Krisis COVID-19: Meta-Analisis dari Sudut Hasil Belajar yang Diukur. Jurnal Riset Teknologi dan Inovasi Pendidikan (JARTIKA), 4(1), 101 108.

Tanujaya, B., \& Mumu, J. (2020). Students' Misconception of HOTS Problems in Teaching and Learning of Mathematics. Journal of Physics Conference Series, 1657 (1), 012052

Widodo, T \& Kadarwati, S. 2013. High Order Thinking Berbasis Pemecahan Masalah Untuk Meningkatkan Hasil Belajar Berorientasi Pembentukan Karakter Siswa. Cakrawala Pendidikan, 32(1), 161-171. 
Journal of Honai Math, Vol. 4, No. 2, pp. 117-130, Oktober 2021

Payadnya \& Suwija, Analisis Kemampuan Berfikir Tingkat Tinggi Mahasiswa Pada Mata Kuliah Metode Statistika di Era Pandemi Covid-19 